\title{
EFFECT OF GOVERNMENT HEALTH CARE EXPENDITURE ON ENTREPRENEURSHIP GROWTH IN NIGERIA (2001-2015)
}

\author{
Lawal Nureni A. \\ Department of Management and Accounting, \\ Ladoke Akintola University of Technology, \\ Ogbomoso, Nigeria \\ Ojokuku Roseline M. \\ Department of Management and Accounting, \\ Ladoke Akintola University of Technology, \\ Ogbomoso, Nigeria
}

\section{INTRODUCTION}

\begin{abstract}
Developing a virile economy entails adequate performance of the players in the industry as their activities determine the growth of the sector. An improvement in health status of the citizenry is an important pre-requisite for achieving human capital development in every economy with its multiplier effect in skillful, efficient and productive investment in human capital that will translate into required capabilities for entrepreneurship growth for overall economic development The inadequacy noticed in government spending in the Health sector with its attendant negative effect on performance underscored the need for the study into the effect of government health care expenditure on entrepreneurship growth in Nigeria. Specifically, the study analyzed the effect of government health care expenditure on employment, share of GDP and share of export (indices of entrepreneurship growth) in Nigeria between 2001 and 2015. Data generated was analyzed using Multivariate Regression technique. The regression result showed that government health care expenditure is a significant predictor of employment at a ft - value of 20.249 and $t$ value of 3.224, share of GDP at a $\beta$-value of - 10.511 and $t$-value of - 4.121 and share of export at a $\beta$-value of 46.647 and $t$-value of 0.000 . This implies that government health care expenditure had significant positive effect on entrepreneurship growth during the study period. The study therefore recommended that government should pay more and responsive attention to the issue of health of its citizen for optimal productivity in entrepreneurship in Nigeria.
\end{abstract}

Key Words: Entrepreneurship, Economic Development, Growth,
The recent economic diversification drive in Nigeria has caused a shift in focus from oil to entrepreneurship subsector as vehicle for sustainable national economic development. It is the latest belief that entrepreneurship will drive the global economy in the coming millennium and attention has also been towards technologically oriented economy. With the entrepreneurial shift from manufacturing to services and the increasing importance of new technologies in developed countries, the human capital needs of the entrepreneur and other labour force have changed. Intuitively, it can be concluded that there is an increasing role for mental health and acuity for knowledge workers providing high-end services. Further research in the field of psychology has found that populations in developed countries experienced steady gains in intellectual ability over the course of the $20^{\text {th }}$ century and this is attributable to improvements in health and nutrition (WHO, 1999).In all, the health status of entrepreneurs seeing as major component of human capital formation is very crucial in achieving set targets (Rasaki, 2011).

\section{Statement of the Problem}

Macroeconomics research on productivity emphasized the importance of human capital in the form of health status (Emile, 2002). Fogel (1991), highlights the significance of population health for productivity by providing compelling evidence for the important role of nutrition, particularly in the infant stage, on health and functioning throughout the life cycle, since independence, the pattern of health financing has been closely and indivisibly linked to the quality of health outcomes (health status) which is capable of attaining the long term objective of promoting nation's economic development (Riman, 2012). Realizing the importance of health and as an evidence of commitment towards the restructuring of the health sector in its fiscal 


\section{International Journal of Engineering Applied Sciences and Technology, 2019 \\ Vol. 4, Issue 3, ISSN No. 2455-2143, Pages 316-321 \\ Published Online July 2019 in IJEAST (http://www.ijeast.com)}

operation, the Nigerian government took up the responsibility of providing good health care facilities for its citizens by improving on the amount of its expenditure on health. Available data revealed that on the average, about $2.1 \%$ to $5.8 \%$ of the total government spending was expended on health within 2000 and 2007 (Mordi, 2010).

However, despite this level of significance of health of the people in the country and government's effort, expenditure of government in this regard has been low compare to World Health Organization's recommendation (Rasaki, 2011). Statistics have indicated that Nigeria's public spending on health as a percentage of GDP is 4.1 percent against 4.6 percent African average and over 6.3 percent in advanced countries. With the various attempts, Nigeria overall health position on sector performance outcomes have not been so encouraging. According to Yaqub (2010), the country overall health performance was ranked $187^{\text {th }}$ among the 191 member states by the World Health Organization (WHO) in 2000. The rate of life expectancy is only 49.8 years compared with 53.5 years for SubSaharan Africa, 65.4 years for developing countries in 2007, while in 2011, Nigeria only managed to achieve marginal improvement with value of 51.7 (World Bank, 2013). Nigeria known to be the largest country in subSaharan Africa with high level oil deposit has continued to experience health problems in the forms of high rates of infant mortality and maternal mortality due to prevalence of different diseases (Rasaki, 2011). This high mortality rate has however resulted in low life expectancy despite government's huge resources from oil (Rasaki, 2011). This, according to literature resulted from the fact of lip service that is paid to issue of health care services by successive government of the land. These various developments however necessitated a further review of the effect of government health care expenditure on selected entrepreneurship growth indices in Nigeria. This study therefore examined the effect of government health care expenditure on selected entrepreneurship growth indices (employment, share of GDP and share of export) in Nigeria between 2001 and 2015. The hypothesis formulated for the study is:

Ho: Government health care expenditure has no significant effect on selected entrepreneurship growth indices in Nigeria between 2001 and 2015 .

\section{Relevance of the study}

Health status of individual entrepreneur and employees is crucial in achieving set targets and for this reason, government expended towards ensuring that all citizens are exposed to sound health care systems. Overtime, it's been observed that budgetary allocation to health care has been reducing beginning from 1999. The implications of this on the ability of people to start and manage their own businesses underscored the need to study further on the relationship between government health care expenditure and entrepreneurship growth in Nigeria.

\section{LITERATURE REVIEW}

\section{Health Care Scheme in Nigeria.}

According to Onota and Nwankwo (2012), defining exactly what a care system is remains a herculean task but can be considered to include all the activities whose primary purpose is to promote, restore or maintain people's health. The health system have a responsibility not just to improve people' health but to protect them against the financial costs of illness thus increasing the level of their productivity in terms of performance and their available wealth for productive commerce. The focus of authors in the past had been on investment on education and training as tools for human capital formation while the issue of health had been underplayed with little or no attention to it as viable tool for human capital formation. Rasaki (2011) while reacting to this issue made reference to the work of Grossman (1972a \& b) which shifted attention to the strategic importance of health in human capital formation and its contribution to economic growth and development and thus concluded that the importance of individual's health when discussing their productive capacity cannot be over-emphasized.

From independence, there were three major attempts at creating and sustaining a people oriented health system in Nigeria (Ejemai, 2014). The first attempt of health care system launching was between 1975 and 1980 when Basic Health Service Scheme (BHSS) was introduced. It came as an integral part of Nigeria's Third National Development Plan (1975 - 1979) with the creation of twenty (20) health clinics across each Local Government and backed with major four (4) health centres targeting treatment of approximately one hundred and fifty thousand $(150,000)$ populations each. This however failed because the local communities targeted for the scheme were not involved in its implementation (Adeyemo, 2005).

The second attempt christened model primary health care came up under the leadership of Professor Olikoye Ransome Kuti between the period of 1986 and 1991 with pilot schemes in fifty two (52) Local Governments. It recorded about $80 \%$ of complete immunization of children under age five. The steadfastness of the minister then informed the success recorded for the scheme (Ejemai, 2014). Thereafter, the programme witnessed a negative trend in term of development.

The third attempt heralded the introduction of the National Primary Healthcare Development Agency (NPHCDA in 1992. To drive this new policy, over five hundred (500) model health centres were established across the nation by the Federal Government to serve as a fulcrum for the establishment of the Ward Health System and mobilization of the Community (NPHDA, 2012). The minimum service components of Primary Health Care include education concerning health problems and the methods of preventing and controlling them; promotion of proper nutrition; an adequate supply of safe water and basic sanitations; 


\section{International Journal of Engineering Applied Sciences and Technology, 2019 \\ Vol. 4, Issue 3, ISSN No. 2455-2143, Pages 316-321 \\ Published Online July 2019 in IJEAST (http://www.ijeast.com)}

maternal and child health care including family planning; immunization against major infectious diseases; appropriate treatment of common diseases and injuries and provisions of essential drugs (Alenoghena, Aigbiremolen, Abejegah \& Eboreime, 2014),

Historically, health insurance in Nigeria can be applied to a few instances; free health care provided and financed for all citizens, health care provided by the government through a special health insurance scheme of government employees and private firms entering into contracts with private health care providers. The level of funding available to the health sector has always been course for concern as most of these health developmental programmes were faced with challenges.

In May 1999, government created the National Health Insurance Scheme, to cover government employees, the organized private sector and the informal sector. In 2004, the administration of Chief Olusegun Obasanjo further gave more legislative powers to the scheme with positive amendments to the original 1999 legislative Act. This move was to give clean bill of health to employees and other stakeholders in the economy such that their productive capacities will further be enhanced (Monye, 2012). The challenge of this scheme is the extent of it coverage as it is limited only to employees in some organizations and does not target individuals on the street who may not have any link with particular organizations. This is a major problem as entrepreneurship is an all comer's affairs without restrictions once the individual or group are having skills and necessary capital to take off.

\section{The Concept of Entrepreneurship}

Entrepreneurship is known as the capacity and attitude of a person or group of persons to undertake ventures with the probability of success or failures. Entrepreneurship demands that the individual should be prepared to assume a reasonable degree of risks, be a good leader in addition to being highly innovative (Onwubiko, 2008). Gross (2005), defined entrepreneurship as the effective manipulation of human intelligence as demonstrated in a creative performance.

Entrepreneurship in Nigeria is perceived as a major avenue to increase the rate of economic growth, create job opportunities, reduce import of manufactured goods and decrease the trade deficits that result from such imports (Onwubiko, 2008). This perception is hinged on the fact that entrepreneurship is a mental activity undertaken by individuals or groups as a result of their skills, experiences and capabilities. To achieve optimal performance in entrepreneurship, Rasaki (2011) posited that health status of individual owner manager and employees become important. He thus found that a strong correlation exists between health status and individual's level of productivity.

\section{THEORETICAL REVIEW}

Endogenous growth theory places emphasis on human capital investment as the engine of economic growth (Romer 1986; Lucas, 1988). The proponents of the theory posit that economic growth is primarily the result of endogenous factors such as human capital (skill, entrepreneurship, knowledge, health status, information and communication (Romer, 1990; Barro \& Lee, 1993). The endogenous growth theory sees the quality of labour in terms of education and skill as the pivotal long run economic growth. The endogenous growth models broadly divided into two major components. First, the NelsonPhelp (1996) viewpoint which acknowledges domestic knowledge creation through innovation and technology transfer and second, the Lucas (1988) components which underscore differences between those that invest in education and health care schemes and those that did not. The application of this theory in the current study will model growth expected from entrepreneurship as a function of human capital formation and presents in a single aggregate Cobb - Douglas production function given as:

$Y=F\left(K, H_{j} A L\right) \ldots \ldots \ldots \ldots \ldots \ldots \ldots \ldots \ldots$ Eq. 1.1

where $\mathrm{H}=$ government expenditure on education and health care facilities, $\mathrm{Y}=$ Entrepreneurship growth, $\mathrm{L}=$ labour force, and $\mathrm{K}=$ physical capital. In the theory, Solow augmented model becomes more plausible if capital (k) is seen from a broader scope to include human capital $(\mathrm{H})$ as modest fundamental factor in the growth process. Lee and $\mathrm{Yu}$ (2005) assert that investment in human capital (investment in education and health care schemes) lead to technological change and this is the main departing point of the endogenous growth model from the exogenous growth model.

\section{METHODOLOGY}

Time series data between 2001 and 2015 on government health care expenditure in Nigeria were used. The data were obtained from the Central Bank of Nigeria $(\mathrm{CBN})$ Statistical Bulletin, Nigeria Bureau of Statistics (NBS) and World Bank Data Base. Multivariate regression technique .was used to test the data gathered to examine the effect of government health care expenditure on entrepreneurship growth in Nigeria between 2001 and 2015. The study used contribution to employment, share of GDP and share of export as indices for entrepreneurship growth. For purpose of the study, the relationship between government health care expenditure and the selected entrepreneurship growth indices is model thus:

$\mathrm{EG}=\mathrm{f}(\mathrm{GEH})$ where

$\mathrm{EG}=\mathrm{Po}+\mathrm{Pi} \mathrm{GEH}+\mathrm{e}$, where

$\mathrm{Po}=$ Constant, $\mathrm{Pi}$. $\mathrm{Pn}=$ Parameter estimate for the explanatory variable and $\mathrm{e}=$ error term. Hypothesis Testing 
Ho: Government health care expenditure has no significant effect on selected entrepreneurship growth indices ip Share of Export Nigeria between 2001 and 2015.

Table 1: parameter estimates for employment contribution

\begin{tabular}{|c|c|c|c|c|c|c|}
\hline \multirow[t]{2}{*}{$\begin{array}{l}\text { Dependant variable } \\
\text { Parameter }\end{array}$} & \multirow[t]{2}{*}{$\beta$} & \multirow{2}{*}{$\begin{array}{l}\text { Std. } \\
\text { Erro } \\
\text { r }\end{array}$} & \multirow[t]{2}{*}{$\mathrm{T}$} & \multirow[t]{2}{*}{ Sig } & \multicolumn{2}{|c|}{$\begin{array}{c}\text { 95\% Confidence } \\
\text { Interval }\end{array}$} \\
\hline & & & & & $\begin{array}{l}\text { Lowe } \\
r \\
\text { Boun } \\
d\end{array}$ & $\begin{array}{l}\text { Upper } \\
\text { Bound }\end{array}$ \\
\hline Employment & 1.15 & .53 & 2.1 & .03 & .095 & 2.21 \\
\hline Intercept & 7 & 7 & 55 & 3 & 7.82 & 8 \\
\hline Contribution & 20.2 & 6.2 & 3.2 & .02 & 9 & 32.6 \\
\hline $\mathrm{EH}$ & 49 & 80 & 24 & 2 & & 68 \\
\hline
\end{tabular}

Level of Significances: 5\%

The result of the Parameter of Estimate for Contribution to Employment showed that Government health care expenditure (GEH) positively affected employment contribution with equation $\mathrm{EMC}=1.157+20.249 \mathrm{EH}+\mathrm{e}$. It implied that when GEH is held constant, employment contribution.

Table 2: Parameter Estimates for Share of GDP

\begin{tabular}{|ll|r|r|r|r|r|}
\hline Source & $\begin{array}{c}\text { Dependent } \\
\text { Variable }\end{array}$ & \multicolumn{1}{|c|}{$\begin{array}{c}\text { Type III } \\
\text { Sum of }\end{array}$} & Df & \multicolumn{1}{c|}{$\begin{array}{c}\text { Mean } \\
\text { Square }\end{array}$} & \multicolumn{1}{|c|}{ F } & \multicolumn{1}{c|}{ Sig. } \\
\hline EMC & .116 & 1 & .116 & 10.396 & .002 \\
& & .031 & 1 & .031 & 16.111 & .000 \\
EH SG & & & & & \\
& SE & .617 & 1 & .617 & 139.481 & .000 \\
\hline
\end{tabular}

Level of Significance: $5 \%$

The result of the Parameter of Estimate for share of GDP showed that Government health care expenditure (GEH) negatively affected share of GDP with equation SG = $0.632-10.511 \mathrm{EH}+\mathrm{e}$. It implied that when GEH is held constant, share of GDP assumed $p=-10.511$ and $t$ statistics “ - 4.014 indicating a significant negative relationship (causal) between GEH and share of GDP.

Table 3: Parameter Estimates For share of Export

\begin{tabular}{|l|c|c|c|c|c|c|}
\hline Dependant variable Parameter & B & Std. & $\mathrm{T}$ & Sig & \multicolumn{2}{|c|}{$95 \%$ Confidence } \\
& & Error & & & \multicolumn{2}{|c|}{\begin{tabular}{l} 
Interval \\
\cline { 3 - 5 }
\end{tabular}} \\
& & & & & $\begin{array}{c}\text { Lower } \\
\text { Bound }\end{array}$ & $\begin{array}{c}\text { Upper } \\
\text { Bound }\end{array}$ \\
\hline
\end{tabular}

Level of Significance: $5 \%$

Findings from the Parameter of Estimate for Share of Export showed that Government health care expenditure (GEH) positively affected share of export with equation $\mathrm{EMC}=1.031+46.647 \mathrm{EH}+\mathrm{e}$ It implied that when GEH is held constant, share of export assumed $(3=46.647$ and $t$ Statistics $=11.810$ indicating $\mathrm{a}$ significant positive relationship (Causal) between GEH and share of export.

Table 4: Regression Result

\begin{tabular}{|c|c|c|c|c|c|c|c|}
\hline \multirow[t]{2}{*}{ Dependent Variable } & \multirow[t]{2}{*}{ Parameter } & \multirow[t]{2}{*}{$\beta$} & \multirow[t]{2}{*}{ Etd. } & \multirow[t]{2}{*}{$\mathrm{T}$} & \multirow[t]{2}{*}{ Sig. } & \multicolumn{2}{|c|}{ 95\% Confidence Interval } \\
\hline & & & & & & $\begin{array}{l}\text { Lower } \\
\text { Bound }\end{array}$ & $\begin{array}{l}\text { Upper } \\
\text { Bound }\end{array}$ \\
\hline \multirow[t]{2}{*}{ Share of GDP } & Intercept & -.632 & .224 & -2.824 & .005 & -1.075 & -.189 \\
\hline & EH & -10.511 & 2.619 & -4.014 & .000 & -15.690 & -5.332 \\
\hline
\end{tabular}

Level of Significance: $5 \%$

The result of the hypothesis tested as shown on Table 4, revealed that government expenditure on health care had significant effect on contribution to employment at $\mathrm{p}=0.002$, on contribution to GDP at $\mathrm{p}-0.000$, and on contribution to export at $\mathrm{p}=0.000$. Also, the calculated Fvalue of 10.396 for contribution to employment, $F=16.111$ for share of GDP and $\mathrm{F}=139.481$ for share of export as shown in table 4 were greater than the critical $\mathrm{F}$ - value at $5 \%$ level of significance. This showed that significant relationship exist between government health care expenditure and entrepreneurship growth indices (The model is of good fit). Hence, the null hypothesis was rejected while alternative hypothesis accepted. This implies that government expenditure on health care has significant effect on entrepreneurship growth within the period of the study.

\section{DISCUSSION OF FINDINGS}

The objective of the study was to examine the effect of government health care expenditure on entrepreneurship growth in Nigeria between 2001 and 2015. Findings as shown in the Table revealed that government health care expenditure has relationship with the indices of entrepreneurship growth (contribution to employment, share of GDP and share of export). The regression result showed that government health care expenditure is a 


\section{International Journal of Engineering Applied Sciences and Technology, 2019 \\ Vol. 4, Issue 3, ISSN No. 2455-2143, Pages 316-321 \\ Published Online July 2019 in IJEAST (http://www.ijeast.com)}

significant predictor of SMEs contribution to employment at a - value of 20.249 and $t$-value of 3.224, share of GDP at a (3-value of-10.511 and t-value of - 4.121 and share of export at a p-value of 46.647 and $t$-value of 0.000

Further findings from the result of the hypothesis tested reveals that government health care expenditure had significant effect on contribution to employment at $\mathrm{p}=0.002$, on contribution to GDP at $\mathrm{p}=.000$, and on contribution to export at $\mathrm{p}=0.000$. Also, the calculated Fvalue of 10.396 for contribution to employment, $\mathrm{F}=16.111$ for share of GDP and $\mathrm{F}=139.481$ for share of export as shown in Table 3 were greater than the critical $\mathrm{F}$ - value at $5 \%$ level of significance. This showed that significant relationship exist between government health care expenditure and entrepreneurship growth indices (The model is of good fit). Hence, the null hypothesis was rejected and thus showed that government health care expenditure had significant effect on entrepreneurship growth within the period of the study.

This position was supported by Bloom \& Canning (2000), who argued that when labour is healthy, their incentive to develop new skills and knowledge is higher because they expect to enjoy long term benefits. But when the labour force is characterized by workers with poor health, they turn to have an adverse effect on productivity. This according to the duo explains the disparity in development in different regions of the world and hence the need for government in this part of the world to focus more spending on health of their working population.

However, Serge and Julius (2017), though in support of the above position find a correlation between government expenditure on health and economic growth via entrepreneurship, they argued that other accommodating conditions have to be in place for optimal response of health expenditure. They maintained that governance related issues should assure that health investments are directed at improving health stand of the population for effective performance.

In furtherance of this argument, Rasaki (2011) concluded that a strong correlation exists between health status and individual's level of productivity. He argued that the health status of entrepreneurs seeing as major component of human capital formation is very crucial in achieving set targets. Rasaki (2011) while reacting to this issue made reference to the work of Grossman (1972 a \& b) which shifted attention to the strategic importance of health in human capital formation and its contribution to economic growth and development and thus concluded that the importance of individual's health when discussing their productive capacity can not be overemphasized.

Furthermore, Jhingan (2005), opines that in its wider sense, investment in human capital means expenditure on health, education and social service in general. It seeks to improve the productivity of the individual and make him more useful to society. Appleton and Teal (1998) in their own reaction describe health and education as components of human capital that are contributors to human welfare. They describe these components as different from other types of goods produced in the societies. While high incomes may be conducive to health, it cannot be directly purchased like material goods and services. Within the context of the study, it can be concluded that successful outing or performance of entrepreneurs and their workforce for optimal productivity is a function of improved health status of the players in the firm or industry. A case of underfunding of the heath sector and non-prioritizing of policies in this direction will sure promote negative productivity in the industry.

\section{CONCLUSION}

An improvement in health status of the citizenry is an important pre-requisite for achieving human capital development in every economy with its multiplier effect in skillful, efficient and productive investment in human capital that will translate into required capabilities for entrepreneurship growth for overall economic development. The study revealed that a significant causal relationship exist between the expenditure of government on health care and entrepreneurship growth. Rom this assertion, it is expedient to conclude that the nation's economy will witness a boom via the growth of entrepreneurial activities by the populace resulting from adequate exposure to good health care system. It is recommended that government should pay more and responsive attention to the issue of health of its citizen for optimal productivity.

\section{REFERENCES}

Adeyemo D.O. (2005). Local Government and Health Care Delivery in Nigeria: A Case Study.

J. Hum Ecol 18(2): (pp.149- 160).

Appleton S., and Teal F. (1998),'Human Capital and Economic Development', Economic Research Paper, No. 39.

Barro R., and Lee J.w. (1993). International Comparisons of Education Attainment. Journal of Monetary Economics, 86:(pp.363-394).

Bloom D.E., and Canning D. (2000). Demographic Change and Economic Growth in Asia. Suppl.Popul. Dev. Rev. 26: (pp. 257 - 290).

Ejemai E. (2014). Primary Health Care in Nigeria: from Conceptualization to Implementation. Journal of Medical and Applied Biosciences. 6(2).

Fogel, D.S., and Gnyawali D.R. (1994). “ Environments for Entrepreneurship Development:Key

Dimensions and Research Implications. Entrepreneurship: Theory And Practice. 18(4).

Gross D. (2005). "Schumpeter's Legacy? Interaction and Emotions in the Sociology of Entrepreneurship". Entrepreneurship Theory and Practice, 29(2): (pp.205208).

Grossman M. (1972b). The Demand for Health: A 
Theoretical and Empirical Investigation. New York Columbia University Press for the National Bureau of Economic Research.

Grossman M. (1972a). On the Concept of Health Capital and the Demand for Health. Journal of Political Economy. 80(2), (pp.223 - 255).

Jhingan M.L. (2005), The Economics of development and Planning (Thirty Eight edition) Vrinda Publications (P) Ltd. Delhi, India.

Lucas S.R. (1988); 'The Mechanics of Economic Development' Journal of Monetary Economics (pp. 30-42) Monye F. (2012). An Appraisal of National Health Insurance Scheme of Nigeria.

Commonwealth Law Bulletin, 32(2): (pp.415 - 427).

National Primary Health Care Development Agency (2012). National Guidelines for the Development of Primary Health Care System in Nigeria. Abuja NPHCDA.

Nelson, R., \& Phelps, E. (1966). Investment in Humans, Technological Diffusion, and Economic Growth. American Economic Review, 56: (pp.69-75).

Onotai L.O., and Nwakwo N.C. (2012). A Review of the Nigerian Health Care Funding System and How it Compares to that of South Africa, Europe and America. Journal of Medicine and Medical Sciences. Vol. 3(4), (pp. $226-231)$.

Onwubiko C.M. (2008). Nigeria's Imperative for YouthLed Entrepreneurial Development Publication of Centre for International Private Enterprise (CIPE).

Rasaki S.D. (2011). Health as a Component of Human Capital Formation: Does it Matter for Growth of the Nigerian Economy? Journal of Canadian Social Science..4: (pp.207-218).

Romer P.M. (1986). Increasing Returns and Long-Run Growth. Journal of Political Economy, 94(5): (pp. 10021037).

Romer P.M. (1990). Human Capital and Growth: Theory and Evidence. National Bureau of Economic Research, Nber Working Paper No. 3173.

Serge M.P., and Julius C.T. (2017). Health Expenditure and Economic Growth: A Review of the Literature and an Analysis between the Economic Community for Central African States (CEMAC) and Selected African Countries. Journal of Health Economic Review. Vol.7

\section{Acknowledgement}

We acknowledge the assistance of Dr. Akinyele Idowu and Dr. Oladejo Kayode in gathering data used for the research work. We equally acknowledge Mr. Ibrahim Raji for typesetting and arrangement of the documents. 